\title{
Technological Learning in the Energy Sector
}

\section{Lessons for Policy, Industry and Science}

Edited by Martin Junginger, Wilfried van Sark and André Faaij, Utrecht University, The Netherlands

'This expert analysis provides an important contribution to understanding the technicalities of energy technology cost dynamics. Given the urgent need for delivery of low-cost renewable energy technologies in particular, it is vital to understand how to accelerate this process of technological learning.'

\section{- Miguel Mendonca, World Future Council, Germany}

"Experience curves" are an important instrument for policy makers. This book has a thorough discussion of such "curves" for a large number of energy technologies and will therefore be very useful around the world.'

\section{- José Goldemberg, University of São Paulo, Brazil}

Technological learning is a key driver behind the improvement of energy technologies and subsequent reduction of production costs. Understanding how and why production costs for energy technologies decline, and whether they will continue to do so in the future, is of crucial importance for policy makers, industrial stakeholders and scientists alike. This timely and informative book therefore provides a comprehensive review of technological development and cost reductions for renewable energy, clean fossil fuel and energy-efficient demand-side technologies.

It responds to the need for a quality-controlled data set of experience curves, including assessment of measurement methodology, technological knowledge and associated cost. The expert contributors present a thorough overview and discussion of the pitfalls of applying the experience curve approach, including aspects such as geographical system boundaries, whether the slope of the experience curves is constant or not, statistical error and sensitivity analysis of experience curves, and whether the experience curve approach can be utilized to quantify improvements in energy efficiency. A clear set of recommendations for the use of the experience curve approach is also prescribed.

Providing a significant contribution to the current literature on energy and climate models, scenario analysis, and methodological lessons on experience curves, this book will strongly appeal to academics and students in the areas focusing on energy and public sector economics. Policy makers in these fields will also find the book to be of great interest.

Contributors include: E. Alsema, A. Bergek, L. Dale, P. de T'Serclaes, W. Engels, A. Faaij, R. Hoefnagels, M. Jakob, M. Junginger

S. Kahouli-Brahmi, P. Lako, S. Lensink, R. Madlener, M. McNeil, D. Milborrow, L. Neij, G. Nemet, M. Patel, A. Ramírez Ramírez, G. Rothwell,

E. Rubin, G.-J. Schaeffer, T. Simon, R. Suurs, W. Taelman, M. van den Broek, A. van Heek, W. van Sark, G. Verbong, M. Weiss, C.-O. Wene, S. Yeh

Aug 2010352 pp Hardback $9781848448346 £ 85.00$ • Ebook 9781849806848

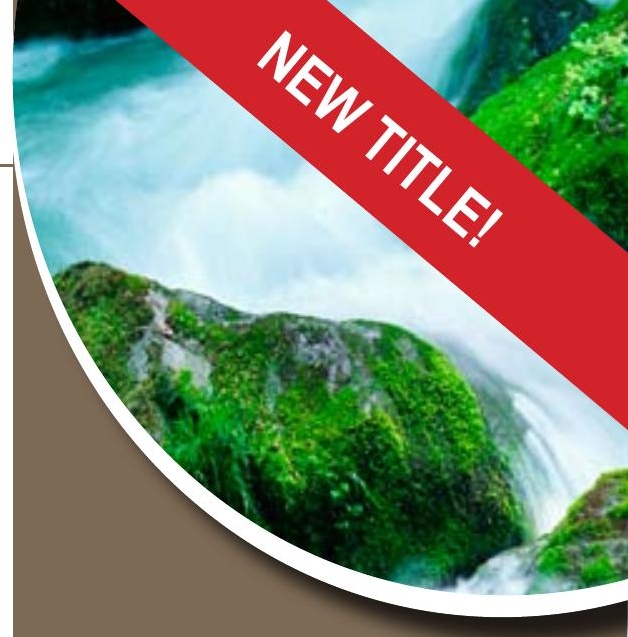

TO ORDER THIS TITLE, PLEASE CONTACT:

Marston Book Services Limited 160 Milton Park

Abingdon, Oxon

OX14 4SD UK

Tel: +441235465500

Fax: + 441235465555

direct.order@marston.co.uk

\section{FOR FURTHER INFO, \\ PLEASE CONTACT:}

Sales and Marketing Department

Edward Elgar Publishing Limited

The Lypiatts

15 Lansdown Road

Cheltenham, Glos

GL50 2JA UK

Tel: + 441242226934

Fax: + 441242262111

www.e-elgar.com

For your free catalogues email: info@e-elgar.co.uk
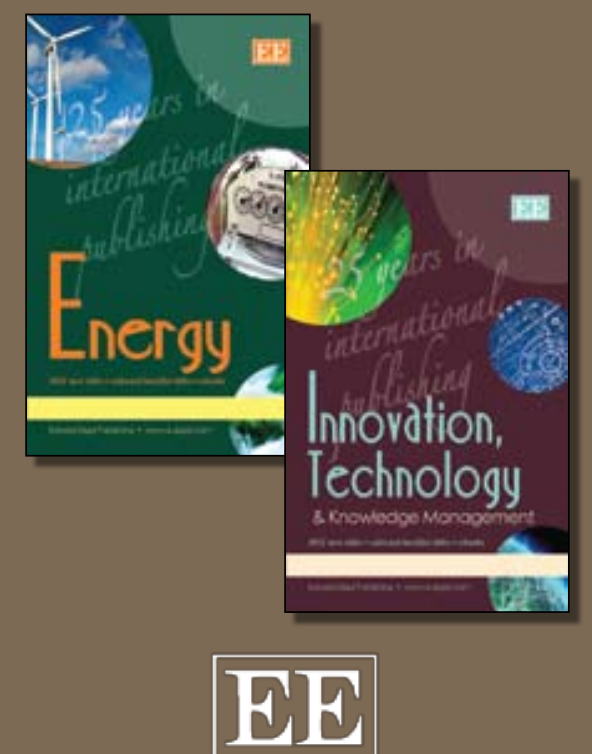

EDWARD ELGAR

P u b I i s h i g H'ww.e-elgar.com

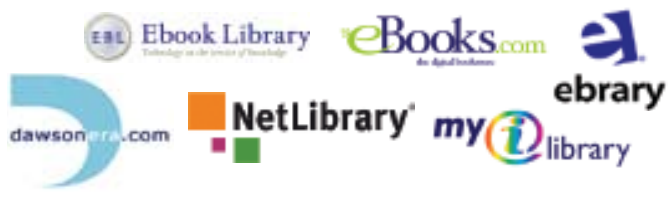

